\title{
The Discount Rate and Market Interest Rates: What's the Connection?
}

\author{
DANIEL L. THORNTON
}

ISCOUNT rate changes invariably send newspaper reporters to the phone to call their favorite economist to ask the inevitable question: What will this do to market interest rates? The impact of discount mate changes on market interest rates apparently is the source of mach public confusion and misunderstanding.

This confusion arises from a variety of factors. First, the discount rate is an administered rate set by the Federal Reserve. Second, high interest rates often occur when the discount rate is high, while low interest rates often occur when the discount rate is low. Finally, discount rate changes often are associated with changes in other interest rates in the same direction. These factors have led to a misunderstanding about the pre-eminence of the dis count rate in credit markets. ${ }^{1}$

The idea of the pre-eminence of the discount rate stems, in part, from a failure to understand the mechanism through which changes in the discount rate are transmitted to market interest rates. The pupose of this article is to analyze the theoretical basis of the link between the discount rate and market interest rates, and to review the recently observed relationship between these rates in light of the theoretical discussion.

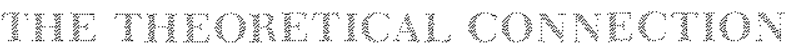 B.

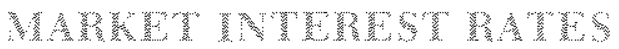

The discount rate is the interest rate at which Fedeal Reserve banks lend reserves to depository institutions, primarily to enable these institutions to meet their reserve requirements. ${ }^{2}$ The relationship

\footnotetext{
${ }^{1}$ For a recent statement on the importance of the discont rate, see

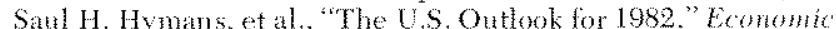
Ontlow USA (Winter 1982), p. 3. For a statement about the discomb rate as a piytal rate in the market, se George Mekeney, The Federal Resene Discont Windat Rutgers University press, 1960 , p. 6.

${ }^{2}$ As a result of the Monetary Contrel Act of 1980 , enacted on $\mathrm{March}$ 31. 1980, all depository institutions will have the sume resere
}

between the discount rate and market interest rates can be illustrated using a simple, static model of interest rates called the lomable funds theory. According to the lomable finds theory, interest rates are determined by the intersection of the demand for and supply of credit, as illustrated in figure 1 . The demand for credit consists of investment demand, govemment demand (deficits) and changes in the demand for money, ${ }^{3}$ The supply of credit is composed of public and private savings and changes in the supply of money. Changes in the discount rate affect market interest rates only to the extent that they alter the demand for or the supply of credit.

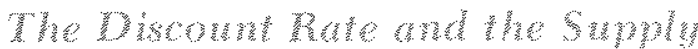 of madk}

Changes in the discount rate directly affect the supply of eredit through their impact on the money supply. To illustrate this, consider the simple model of the money supply given by:

(1) $\mathrm{MS}^{\mathrm{S}}=\mathrm{m} \cdot \mathrm{B}$.

The supply of nominal money (MS) is determined by the product of the monetary base (B) and the money multiplier ( $m$ ). The monetary base consists of the total reserves of depository institutions plus currency held by the nonbank public. The money multiplier summarizes the effect of all other factors on the money supply and, for the pupose of our analysis, is

qequirements. The anifom restre requitements will be phased in over a number of years. For more details, see "The Federal Reserve Refuirements" Boand of Coremors of the Federal Resene System, 1981). The Monetaty Control Act atso has given thrif institutions access to the discomt window through "extended credit bortowing." For more detals, see "The Federal Reserve Diseont Window" (Board of Crovemors of the Federal Reserve System, $1980 \%$.

The smply cure is sloped positively on the assumption that higher interest rates encourage more savings and because the money supply mat be positively related to the interest rite (see lootnote 4 below. The demand for loanble funds is downard sloping due to the downward sloping marginal efficiency of investment and the inverse relationship between the demand for money and interest rates. 
assumed to be constant and independent of market interest rates. ${ }^{4}$

Total reserves supplied by the Federal Reserve can be broken down into those supplied at the discount window, called borrowed reserves (BR), and those supplied through open maket operations, called nonborrowed reserves (NBR). The monetary base, therefore, can be written as the sum of $B R$, NBR and curnency held by the nonbank public (C). Thus, equation 1 can be rewritten as:

(2) $\mathrm{M}^{\mathrm{s}}=\mathrm{m} \cdot(\mathrm{BR}+\mathrm{NBR}+\mathrm{C})$.

Changes in the discount rate affect market interest rates through their impact on borrowing from the Federal Reserve. For example, an increase in the discount rate will reduce the level of borrowing. ceteris paribus, reducing both the monetary base and the money supply. As a result, the supply-ofcredit schedule in figure $I$ will shift to the left and market interest rates will rise. Reducing the discount rate will have the opposite effect.

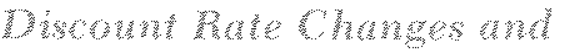

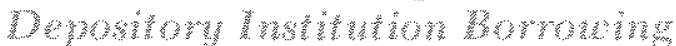

The crucial link between the discount rate and market interest rates is the connection between the discount rate and borrowing from the Federal Reserve. When the discount mechanism originally was formulated, it was assumed that banks would be reluctant to be in debt to the Federal Reserve and would endeavor to repay their indebtedness as soon as possible. ${ }^{5}$ It was thought that the Federal Reserve could control the level of bank borrowing by reinforcing banks' reluctance to borrow, through the administration of the discount window, and by alter-

\footnotetext{
${ }^{4}$ It is sometimes argued that the money supply is positively rem Iated to interest rates due to thanges in the public's desire to hold various assets in response to interest rate changes. For an andysis of the monetary base approach to the money supply process, see Jerry L. Jordan, "Elements of the Money Stock Determination," this Reviex (October 1969), pp. 10-19.

"Winfeld Riefler noted that "the reluctance of member banks to borrow is not based solely upon the philosophy of reserve banks, however. Indeed, that philosophy mexely expresses the destre of the great mainority of the member banks themselves to remain out of debt. . and a feeling on their part that borrowing for profit is unsound. . . Long before the establishment of the teserve system, it was one of the fundamental traditions of sound banking practice in this country, that a bank's operations should be confined to the resonees which it derives from its stockholders and depositors and interbank borrowing was at all times limited." Winfield Riefler, Money Rates and Money Markets in the United States (Harper and Bros., 1930), p. 29.
}

ing the discount rate, ${ }^{6}$ Given the nonpecuniary costs associated with discont window administration, an increase in the discount rate would reduce the level of borrowing; reductions in the discount rate would have the opposite effect.

Later, it was recognized that the relationship between the discount rate and borrowing at the discount window was not quite so simple. Borrowing from the Federal Reserve is only one of several methods depository institutions use to adjust their reserve positions. They can borrow from the Federal Reserve, buy federal hinds in the federal funds market, or sell earning assets, such as short-term Treasury securities. ${ }^{7}$ It is not simply the level of the discount rate that influences a depository institution's decision to borrow, but the level of the discount rate relative to rates on alternative adjustment assets. A financial institution confronted with a reserve deficiency will adjust its reserve position in the least costly manner. Thus, the important variable in the decision to borrow is the so-called least-cost spread between the rate on the next best reserve adjustment asset and the discount rate.

In the aggregate, borrowing is usually represented by an equation like (3) below, in which (id) denotes the discount rate and $\left(i_{a}\right)$ denotes the in terest rate on next best reserve adjustment asset. ${ }^{8}$

(3) $\mathrm{BR}=\mathrm{a}_{0}+\mathrm{a}_{1}\left(\mathrm{i}_{\mathrm{a}}-\mathrm{i}_{\mathrm{d}}\right), \mathrm{a}_{0} \geqslant 0, \mathrm{a}_{1}>0$

In this equation, $a_{0}$ denotes a "frictional" level of

"It is still thought that depository irstitutions are reluctant to borrow from the federal Reserve; however, it has been a longstanding question whether the reluctance is inherent or induced. The use of nonpree rationing at the discount window began as early as 1918. See Clay Andersen, A Halirentum of Federal Reserve Policymaking: 1914-1964 Federal Reserve Bank of Philadelphia, 1965 ).

${ }^{7}$ Prior to september 1968, depository institutions could adjust thet reserve postion by reducing the level of their deposits and hence, required recerves. In September 1968, the Federa Reserve introduced lagted reserve accounting, in which re. quired reserves in the current week are based on deposit levels of two weeks previous.

At the same time, the Federal Reserve changed Regulation D to permit a reserve deficiency carryover equal to 2 percent of required reserves, Depository institutions can also adjust their resere position by arrying over the deficiency into the next reserve week. Carryovers in excess of 2 percent of required reserves are charged a rate 2 pencentage point izbove the lowest discomst rate in effect on the first day of the calendar month in which the deficiency occurs. It should be noted that only bornwing from the Federal Reserve adds reserves to the system as a whole.

whe borrowing equation ustally inc indes varables to measure the degree of reserve pressure of depository institutions, such as the level of or the change in monbonowed reserves. Becanse they have no significanee for our purpose, they were ignored here. 


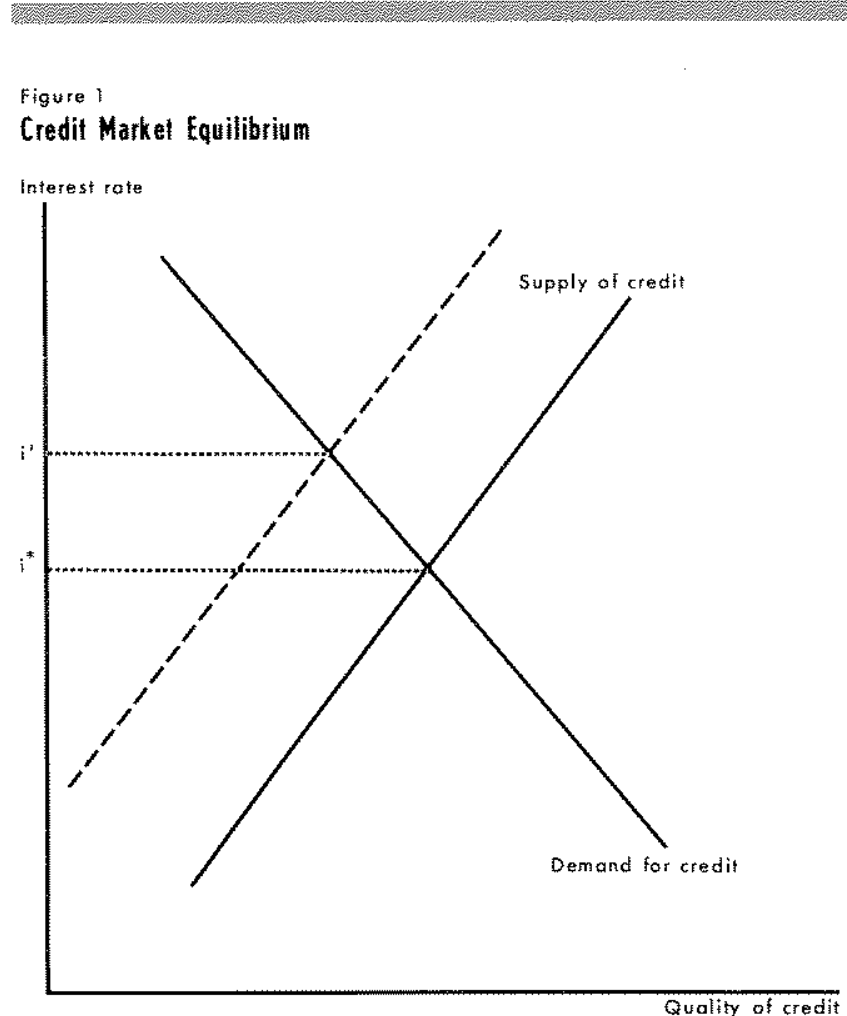

Quality of credit

borrowing (i.e., borrowing that occurs even if the discount rate is not the least costly altemative). ${ }^{9}$

Given equations 2 and 3 , the connection between the discount rate and market interest rates is apparent. Increases in the discount rate reduce the least-cost spread, which reduces borrowing and

\footnotetext{
For ad discussion of the varions theories of depository institutions borrowing. see Riefler Money Rates and Momen Markets in the Cnited States; Landin Cume. The Sumply and Control of Money (Harvard University Press, 1934); Robert Tumer, Wember-Bank Borroteing (Oho State Uniwersity Press, 1938); Muray E. Polakoll "Reluctance Elasticity, Least Cost, and Member Bank Borfowing: A Sugrested luteryation," loumal of Finume (March 1960), pp. I-18, Murray Polakof and Willam Siber, "Reluctance and Member-Bazk Borrowing; Additional Evidence," Jourral of Finance (March 1967) pp. 88-92, and Stephen Coldfeld and Edward kne, "The Deteminants of Nenber Batak Borrowing: An Econometrie Study, "Joumat of Findace September 1966), pp. 499-514.

The fact that there is asuatly some level of borrowing even when the discount rate is alove most other short-term maket interest rates is usally construed as prima lacie evidence of the inaleatacy of the altemative mechanisms in providing the reserve iabustment needs of all alepository institutions. At the otherextreme. borrow ing takes the form of a sabsidy if the disconnt rate is substatially below maket mes. See R. Alton Gilbert, "Benefits of Borrowing from the Federal Reserve when the Diseount Rate is Below Market Interest Rates," this Reven (Mard 1979), pp. $25-32$
}

thus the monetary base. As a result, the supply of credit schedule shifts to the left and market interest rates rise until the least cost spread is restored. Thus, increasing the discount rate will, ceteris paribus, cause market rates to increase.

The extent of the increase in the market interest rate is deternined by the sensitivity of borrowing to the least-cost spread (a1) and by the interest sensitivity of the demand for credit. The more borrowing is interest-sensitive to the least-cost spread (i.e., the larger a1), the greater will be the shift in the supply of credit for any change in the discount rate. The larger the shift in the supply of credit, the greater the change in the market interest rate, for any given credit demand curve. Also, the less interest-sensitive the demand for credit (i.e., the steeper the demand curve), the greater the change in the market interest rate for any given shift in the supply schedule resulting from a change in the discount rate.

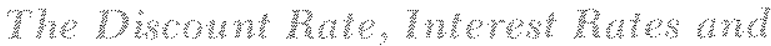

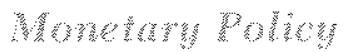

Unfortunately, the above analys is is overly simple in that it ignores the role of monetary policy in influencing the link between the discount rate and market interest rates. Specifically, the relationship between the discount rate and market interest rates depends on other monetary policy actions and, in particular, on the operating procedure of the Federal Reserve. For example, if the Federal Reserve were to pursue a policy of controlling the level of interest rates, changes in the discount rate would have no indevendent impact on maket rates. The reason for this is straightforward. Under an interest rate targeting procedure, the Trading Desk of the Federal Reserve Bank of New York would offset any movement in market rates by changing the level of nonborrowed reserves through open market operations; that is, the leftward shift in the credit supply schedule due to an increase in the discount rate would be offset by a rightward shift resulting from Federal Reserve open market operations. The impact of the change in the discount rate on the market rate would be nil.19

A similar result would hold it the Federal Reserve chose to control the level or growth of the money

\footnotetext{
woIt should be noted that the Federal hesere cammot "per" Interest rates in an inflationary envionment without continaty accelering the growth rate of money. See Milton Friedman,

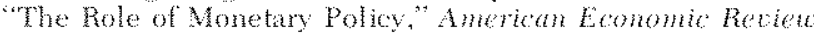
(March 1968), pp 1.17.
} 
supply, and if it effected its control through monetary base (or total reserve) targeting. In this instance, an increase in the discount rate would lower the level of borrowing and, hence, the monetary base. If this change caused the base to deviate from its desired path, given a money growth objective, the Federal Reserve would increase nonborrowed reserves via open-market operations in order to retum the monetary base to its des ired path. Changes in the discount rate would have no independent effect on either the money supply or market interest rates.

The effect of a discount rate change on market rates could be significant when the Federal Reserve targets on nonborrowed reserves as it currently does. In this instance, changes in the discount rate after aggregate borrowing, the monetary base and the money supply as before. The movement in the base would not necessarily be offset th rough open market operations. As long as nonborrowed reserves are on path, the Federal Reserve might choose not to offset changes in borrowings associated with changes in the discount rate. ${ }^{11}$ Under the present system of lagged reserve accounting (LNA), however, the effect of a discount rate change on aggregate borrowing, the monetary base and the money supply will be much smaller.

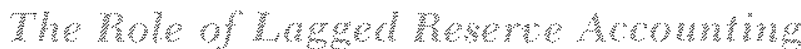

The present system of lagged reserve accounting, which was introduced in September 1968, has made depository institutions' demand for reserves less responsive to interest rate changes. ${ }^{12}$ Thus, any change in the supply of reserves, either through changes in NBR or the discount rate, produces a larger change in the rates on reserve adjustment assets, such as federal funds and Treasury bills.

\footnotetext{
11The reader might legitimately ingaire as to why the Fedemil Reserye would not offet all changes in aggregate borrowing if it did not desire a change in the money supply. Untotunately, there is no smple answerto this question. Recently the Federal Reserve has attempted to oflset changes ha borowing onlu if they are vesed to be permanent in some sense. See David Lindsey, "Nonborrowed Reserve Targeting and Monetay Control" in Improving Honey Stock Control: Problems, Solutions and Consequences, conference cosponsored by the federal heserve Bank of St. Louis and the Center for the Study of Anerican Business, Washington eniversity, October $30-31,1981$ (fortheoming).

It should be noted, however, that if the Fudend Reserve were to offet all changes in borrowings that move then off their nonborrowed reserve path, they would essemtially be targeting on total reserves or the base.

7asine this article was completed, the Federal Reserve Board adopted a resolution to return to contemporanens reserve accounting.
}

In order to see this point, consider the following simple model of the market for reserves. Reserves are supplied by the Federal Reserve either through open matket operations or at the discount window. NBR are detemined solely by Federal Reserve actions and are independent of market interest rates. In contrast, BR are related to interest rates via equation 3. Depository institutions' demand for reserves is composed of their demand for required reserves (as detemined by their deposit levels) and their demand for excess reserves. Under a system of contemporaneous reserve accounting (CRA), both required reserves and excess reserves are assumed to be negatively related to the rate on reserve adjustment assets. ${ }^{13}$ This equilibrium is illustrated in figure $2 \mathrm{a}$ by the intersection of $\mathrm{R}_{\mathrm{s}}$ and $\mathrm{R}_{\mathrm{d}}^{\mathrm{c}}$.

Under a system of LRA, current required reserves are determined by depository institutions' deposits of the prior two weeks. The demand for current required reserces is completely insensitive to the interest rates on reserve adjustment assets. The interest responsiveness of the demand for reserves is determined solely by the demand for excess reserves. Thus, demand for reserves under LRA is less interest-sensitive (steeper), as illustrated by $R_{x}$ in figure $2 \mathrm{~b},{ }^{14}$

The impact of a change in the discount rate under CRA and LRA is illustrated in figure 2. An increase in the discount rate reduces the amount of reserves supplied at each market rate, shifting the reserve supply curve to $R_{s}^{\prime}$. Given that the demand for

\footnotetext{
13Under CRA, depository institutions must weigh the marginal costs of having to adjust their reserve position either at the discount window or in the market with the marginal ga in from making add itional loans and investment and, thereby, creating additional aeposits. Thus, when either the discount rate or the rates on altemative adjustment assets increase relative to depository institutions lending nates, they respond by curtat ing their lending and investment activities, which reduces their deposit linhlities and their demand for required reserves. "Thus, the demind for required reserves wonld be interest sensitive under CRA. Under LRA, the demand for recuired reserves is deternined by deposit levels two weeks previous and, hence, is independent of current interest rates.

Excess reserves are thought to be held as an somec of liquidity for the depository institution. As such the opportuntiy cost of holding exeess reserves is income forgone by not investing them in some income-generating asset, like federal fumds. Thus, the demand for excess reserves is thought to be responsive to changes in market interest rates. The demand for excess reserves, however, is generally not thought to be responsive to interest rates.

14 The equilibrium warket mate is shown the same for both CRA and LRA for ease of illustration. This acommodation to convenience does not alfect the conclusions.
} 
Figure 2

The Effet of Discount Rate Change Under Contemporaneous and Lagged Reserve Accounting
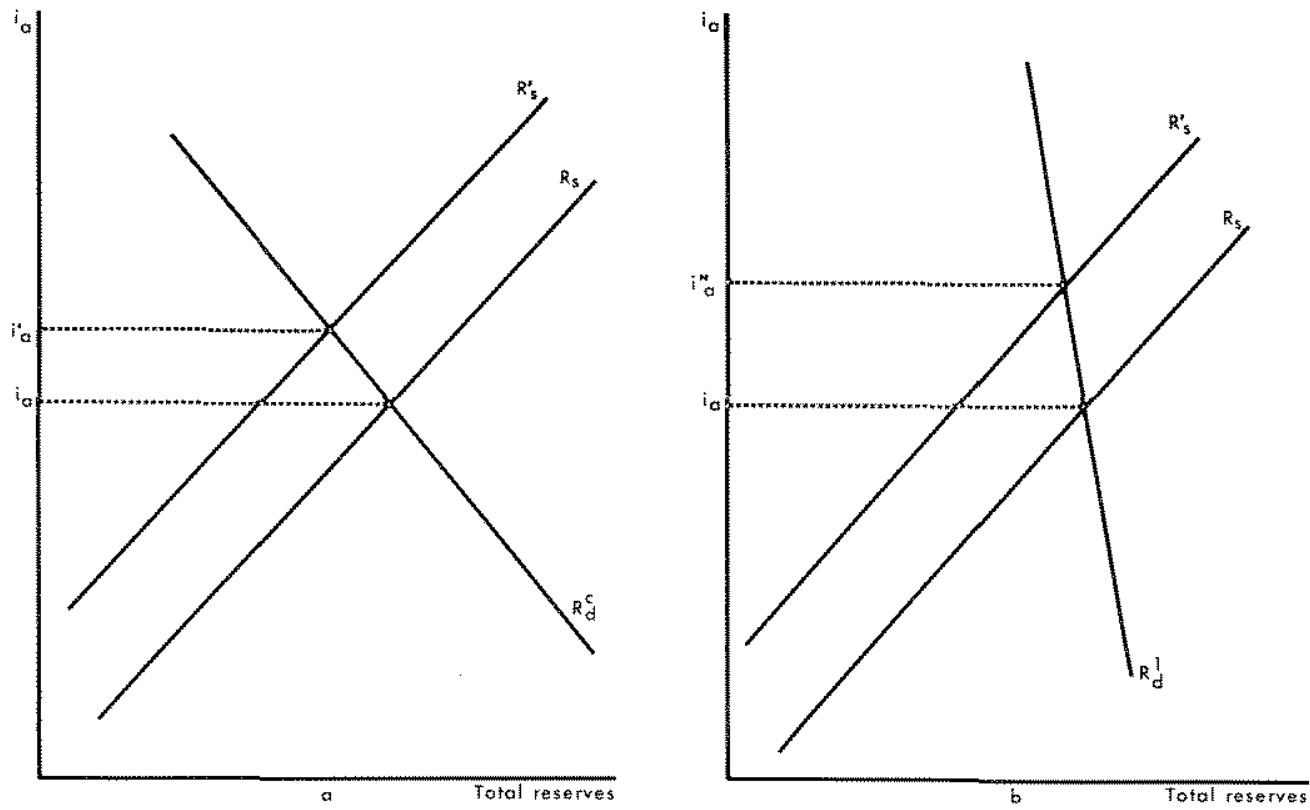

reserves is less interest-sensitive under I RA, interest rates must rise by more in order to restore maket equilibrim. Thus, a change in the discount rate will result in a larger change in the interest rates on reserve adjustment assets, and a smaller change in aggregate borrowing, the monetary base and the money supply.

\section{The Elfect on Other Mratet Rates}

A change in the discount rate has its initial efect on the market interest rate of reserve adjustment assets. The extert to which a change in the market rates of these assets spills over to other market interest rates depends on the substitutability of assets in the portfolios of financial intemediaries and the public. To illustrate this point, assume for simplicity that depository institutions use only one asset as an alternative to borrowing from the Federal Reserve, and that this asset is not held in the port folios of the rest of the private sector of the economy (e.g. federal funds). Thus, there are no close substitutes for this asset in the portfolios of nondepository institutions. In this case, the initial impact of a change in the discount rate would be reflected primarily in the market rate of this asset. The effect on other maket interest rates would materialize only as depository institutions modified their lending and investment activities in light of the higher marginal cost of reserve adjustment funds.

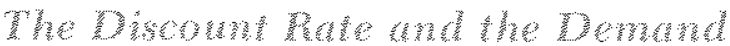 menem}

The discount rate also affects market interest rates via the demard for credit through the so-called amouncement effect. According to this view, the business and financial communities regard discount rate changes as signals of the future direction of monetary policy. Discount rate changes are thus said to alter expectations about the future of business profits and the direction of interest rates.

Unfortunately, the impact of the announcement effect depends on the exact nature of these expectation effects. ${ }^{15}$ To illustrate this, consider the following: If the Federal Reserve increased the discount rate, individuals might interpret this action as an indication that a slower rate of monetary growth, a lower rate of inflation and, hence, lowerinterestrates will soon follow. If this were the case, they might

\footnotetext{
15Warren Smith has arrued that the exact impact of the announcement effect depends on the market perception of the efficacy of monetary policy, the elasticity of interest rate expectations and the distributions of these expectations anong borwowers and lenders in the market. See Warren Smith. "Instruments of Genera Monetary Control, "National Bankinus Retient (September 1963), pp. 47-76; "The Discomnt Rate as a Credit Control Weapon," Joumal of Political Economy (April 1958), pp. 171-77; and "On the Effectiveness of Monetary Policy," American Economic Review (September 1956), pp. 588-606.
} 
Figure 3

Discouni Rate Change and Expectations Effects

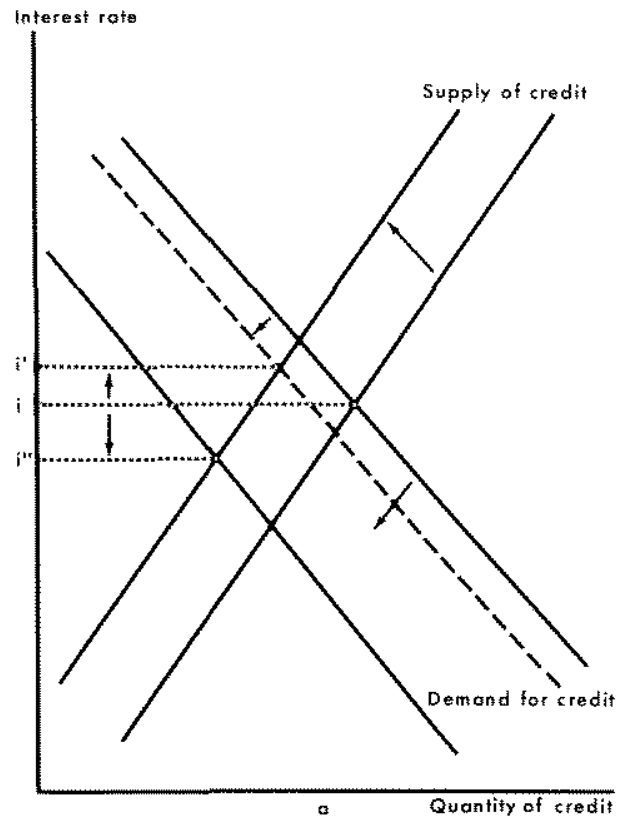

reduce their current demand for credit in anticipa tion of lower future interest rates. The demand for credit would shift to the left and, ceteris paribus, current interest rates would fall. The combined effects of a discount rate increase on the supply of and the demand for credit in this instance, under nonborrowed reserve targeting, are illustrated in figure 3a. An increase in the discount rate shifts both the supply-of-credit and the demand-for-credit schedules to the left. Market interest rates would rise or fall depending on whether the shift in the demand curve is small or large, relative to the shift in the supply curve.

Conversely, individuals might interpret the discount rate increase as an indication that maket interest rates will temporarily rise. In this case, the current demand for credit would increase. Under these circumstances, an increase in the discount rate would shift the supply of credit to the left and the demand for credit to the right as illustrated in figure $3 \mathrm{~b}$. Market interest rates would then have risen in response to a discount rate change. ${ }^{15}$

\footnotetext{
1 Warren Smith has commented that, rather than changing the demand for credit in the short rum, a discount rate increase may merely induce market participants to shift to different tem assets in response to expectations of higher or lower future interest rates. If this were the case, the yield curve would shift with changes in the discount rate. See Smith, "The Discount Rate as a Credit Control Weapon."
}

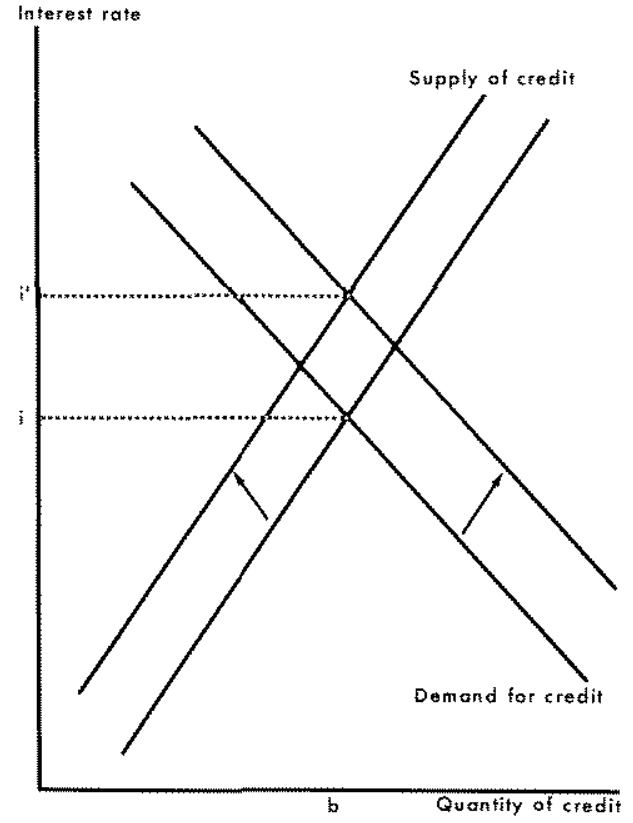

It should be noted, however, that there are those who question whether there should be any significant expectational effect associated with a discount rate change. They argue that a discount rate change is only one of a myriad of signals that individuals receive conceming the direction of economic activity and interest rates; therefore, it is doubtful that changes in the discount rate alone have any significant impact on the demand for credit.

Furthermore, it has been noted that changes in the discount rate are sometimes merely technical adjustments, designed to bring the discount rate in line with changes in market interest rates. Thus, if discount rate changes are commonly interpreted as signals of policy change, they may be misinterpreted. It has even been suggested that, given the Federal Reserve Banks' tendency to make these technical adjustments, a failure to change the discount rate when market rates are changing could be construed as a change in Federal Reserve policy. ${ }^{\mathbf{1 7}}$

\footnotetext{
"7For a recent interpretation of discount rate changes as technical adjustments, see Hymans, et. al., "The U.S. Economic Outlook for 1982." For an interesting look at various interpretations of a discount rate change, see Chatles Walker "Discount Policy in Light of Recent Experience," Journal of Finuthe (May 195\%), pp. 223-37; Milten Friedman, A Prosram for Monetari Stability (Fordham University Press, 1959); and Ralph A. Young, "Tools and Processes of Monetary Policy," in Neil H. Jacoby, ed., United States Monettry Policy (Fredrick A. Proeger $1964)$, pp. $24-72$.
} 


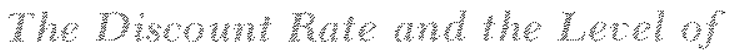

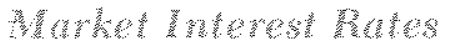

Up to this point, the discussion has been solely in terms of the effect of changes in the discount rate on market interest rates. Nothing has been said about the relationship between the level of the discount rate and the level of market interest rates. Thus, one additional point must be made before proceeding to the empirical analysis. The point is that there are numerous factors that affect the supply of and the denand for credit besides the discount rate. Thus, there is no one level of market interest rates that necessarily corresponds to any given level of the discount rate. It would not be surprising, then, to find that other factors dominate movements in market interest rates in the longer run. This is especially true when one recognizes that the discount rate is an administered rate that is changed infrequently.

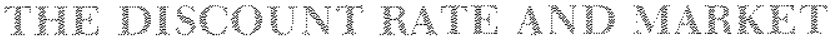

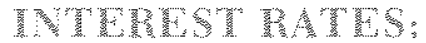 Wh}

Now consider the empirical evidence on the rela tionship between the discount rate and market interest rates. The data analyzed is from January 1978 to April 1982, a period chosen because it is timely and because it is characterized by markedly different Federal Reserve operating procedures. Until October 6, 1979, the Federal Reserve followed a procedure of federal funds rate targeting; that is, it conducted open market operations in such a way as to keep the federal funds rate in a narrow range established by the Federal Open Market Committee (FOMC). Also, the Federal Reserve followed a policy of changing the discount rate frequently to maintain a fairly constant federal funds rate/ discount rate differential.

Since October 1979, the Federal Reserve has pursued a policy of controlling the monetary aggregates through a nonborrowed reserve targeting procedure. ${ }^{18}$ Thus, the amnounced federal funds

\footnotetext{
18 For a discussion of the Federal Reserve's operating procedure since October 6, 1979, see Stephen Axilrod and David E. Lindsey, "Federal Reserve Systen Implementation of Monetary Policy: Analytical Fomdations of the New Appoach," American Economic Retewe (May 1981), pp. 246-52; R. Alton Gilbert and Michael E. Trebing, "The FOMC in 1980: A Year of Reserve Targeting," this Revieu (Angust/September 1981), pp. 2-22; Richard W. Lang, "The FOMC in 1979: Introducing Reserve Targeting," this Revew (March 1980), pp. 2-25; and Lindsey, "Nonborrowed Reserve Targeting and Monetary Control."
}

rate range has been much wider since October 6 , and the federal funds rate has exhibited more day. to-day variability. Moreover, the average daily spread between this rate and the discount rate has been much wider. ${ }^{19}$

Establishing the precise relationship between the discount rate and market interest rates is extremely difficult. Ideally, sets of equations representing the demand for credit, the supply of credit and a market-clearing condition should be specified. In this way, one could not only estimate the extent of the impact of a discount rate change on various market interest rates, but also identify the most significant source of the change (i.e., its effect through the supply of or the demand for credit.$^{20}$ In practice, however, this is difficult. As a result, the impact of a discount rate change on market interest rates is usually estimated with a reduced-form model, which

19For a discussion of the relationship between the federal funds rate and the FOMC's announced federal funds rate range, see Lang, "The FOMC in 1979: Introducing Reserve Targeting"; and Gilbert and Trebing, "The FOMC in 1980: A Year of Reserve Targeting."

${ }^{20}$ One possible way to identify a separate announcement eflect is to specify a genera model of the supply of and the demand for money. This condd be done by simply inelading the discount rate as a separate variable in the demand for money and supply of money functions, and testing to see whether it has a significant effect on either or both. However, the correspondence between the discount rate and market interest rates, due to the fact that discount rate changes tend to follow maket interest rate changes, biatses this test foward the rejection of the an nouncement effect muless one has precise knowledge of the Federd Reserve's discount rate reaction function. This spoblem could be overcome by simply estimating a reduced-form, equilibrim money stock equation. This equation would have the money stock a finction of the exogenous variables of the system: aggregate income, the monetary base and the discount rate.

A significant discount rate effect would be dear evidence of an announcement effect, since the impact of a discount rate change on the money supply would be incorporated in the base Unfortunately, an insignificant discomnt rate will not necessarily imply the absence of an annomeement effect; this result could also be obtained if the money supply is relatively interest-jnelastic. Thus, one would have to show both that the money supply schedule is interestelastic and an insignificant discomt rate in such a reduced-form equation to argue convincingly that there is mo amouncement effect. Regretably, practical problems make this virtually impossible.

It is possble to show that the discom rate is insignificant in a reduced-form equation, employing seasonally adjusted data, for the $10 / 1979-10 / 1981$ period. The money supply equation exhibits some interest elasticity, however, only if selsomally andifusted data is used. Becatse personal income the only avalable monthly income series) is avalable only on a seasonaly adjusted basis, it is impossible to estmate the reducedform equation using seasonally unadjested data. Thus, the insignificint disconn rate variable in the seasonaly adusted, reduced-fom equation is not conclusive evidenee against an amouncement effect. 
does not permit one to differentiate between supplyside and demand-side effects. ${ }^{21}$

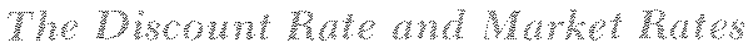

To determine the effect of discount rate changes on market interest rates, the following equation was estimated using both the federal funds and the 3-month Treasury bills to represent alternative adjustment assets:

$$
\text { (4) } \Delta \mathrm{i}_{\mathrm{at}}=\hat{\delta}_{\mathrm{o}}+\sum_{\mathrm{j}=1}^{10} \delta_{j} \Delta \mathrm{i}_{\mathrm{at}-\mathrm{j}}+\delta_{\mathrm{2}} \Delta \mathrm{DR}_{\mathrm{t}}+\epsilon_{\mathrm{t}}
$$

This equation was estimated using daily data for the period from January 10, 1978, to April 13, 1982, and for subperiods of federal funds rate targeting and NBR targeting. ${ }^{22}$ The 10 day distributed lag of the market rate was included to capture the effect of other factors on the market rate before the discount rate change.

Table 1 presents estimates of equation $4 .{ }^{23}$ The change in the discount rate, denoted by $\triangle D R$, equals the change only on the day that it became effective. The $\triangle D R$ variable was partitioned into technical changes- $\triangle D R T$ - and nontechnical changes$\triangle D R N T$ - to test whether there is a different effect if discount rate changes are made solely for technical reasons (i.e., to keep the discount ate in line with market interest rates [see insert, page 12]). ${ }^{24}$

\footnotetext{
21 Among the studies that hive attempted to test for an announcement effect using a reduced-fom model are: H. Kent Baker and Janes M. Meser, "Impact of Disount Pate Changes on Treasury Bills," Jomal of Eomomics and Business (Fall 1980), pp. 43-48; Douglas R. Mudd, "Did Discount Rate Changex Affect the Foreign Exchange Value of the Dollat During 1978?" this Retete (April 1979), pp. 20-26; Rodger Watde "Puble Interpretation of Federal Reserve Discount Rate Changes: Evidence on the "Announcement Effect," Econometrica (Nach 1970), fop, 231.50; and Raymond Lombra and Raymond Torto, "Discount Rite Changes ind Ammotncement Elfects" Quarterly foumal of Economics (February 1977), pe. $171-76$

${ }^{22}$ The data were partitioned on september 19,1979 , the effective date of the lis st discount rate change prior to the implementation of the new operating procednes on Octoben $6,1979$.

${ }^{23}$ The equations were extinated with ordinary least squares (OLS) and with a maximum likelihood procedure that adjusts for forst-order autoconelation. OLS results are reported if the estimate of the coefficient of autoconelation was not significantly different from zero. The results, bowever, were essentially invarime to the estimation technique.

2a Discount rate changes were made for purely technical reatsons on May 11 and July 3,1978 , and an May 30 , June 13 , July 28 , 1980, and December 4,1981 .
}

Also, a discount rate surcharge variable, $\triangle \mathrm{SC}$, was included in some of the regressions in the NBR targeting period to capture any effect of the Federal Reserve's surcharge on large, frequent borrowers. ${ }^{25}$

The results for the entire period indicate that a discount rate change has a significant positive effect on both the federal funds and the Treasury bill rates. When the equation is estimated for subperiods of federal funds rate and NBR targeting, however, the results change. The coefficient on $\triangle D R$ is not significantly different from zero for the Treasury bill rate during the period of federal funds rate targeting. In contrast, the coefficient on $\triangle D R$ is significant for both market rates during the period of $N B R$ targeting. Furthermore, the coefficient estimates on $\triangle D R$ are larger during the latter period.

The preceding section noted that discount rate changes would not affect market interest rates if the Federal Reserve targeted on them, but would affect market rates under NBR targeting. The results for the Treasury bill rate equation correspond with this analysis, but the results from the federal funds rate equation do not. If depository institutions primarily rely on the federal funds market to adjust their reserve positions, however, it is conceivable that most of the impact of a discount rate change could be absorbed by the federal funds rate with virtually no spillover to other market rates. This even seems likely when one recognizes that the Federal Reserve has never followed a policy of rigidly pegging the level of the federal funds rate.

In addition, discount rate changes generally were made in order to keep the rate spread between the discount rate and the federal funds rate in a fairly narrow band during the funds rate targeting period. ${ }^{26}$ Thus, during this period, discount rate changes may have been anticipated and fully reflected in market rates before the discount rate change. The Federal Reserve allowed the spread between the discount and the federal funds rates to be much larger and variable during the NBR target-

\footnotetext{
25The Federd Reserve first introduced at surchirge of 3 percent to the basic discomt rate for large and frequent bortowers on Mareh 77,1980 . The effective surcharges and dates are: 3 percent on March 17,1980 , removed May $7,1980,2$ perent on November 17,$1980 ; 3$ percent on December 5,$1980 ; 4$ percent on May 5, 1981; 3 percent on September 22, 1981,2 perent on October 13, 1981, renoved November 17, 1981.

26The average sprend between the diseomnt and the ledenal funds rates between discount rate changes ranged from 50 to 100 basis points.
} 
Table 1

\section{Estimates of Equation 4}

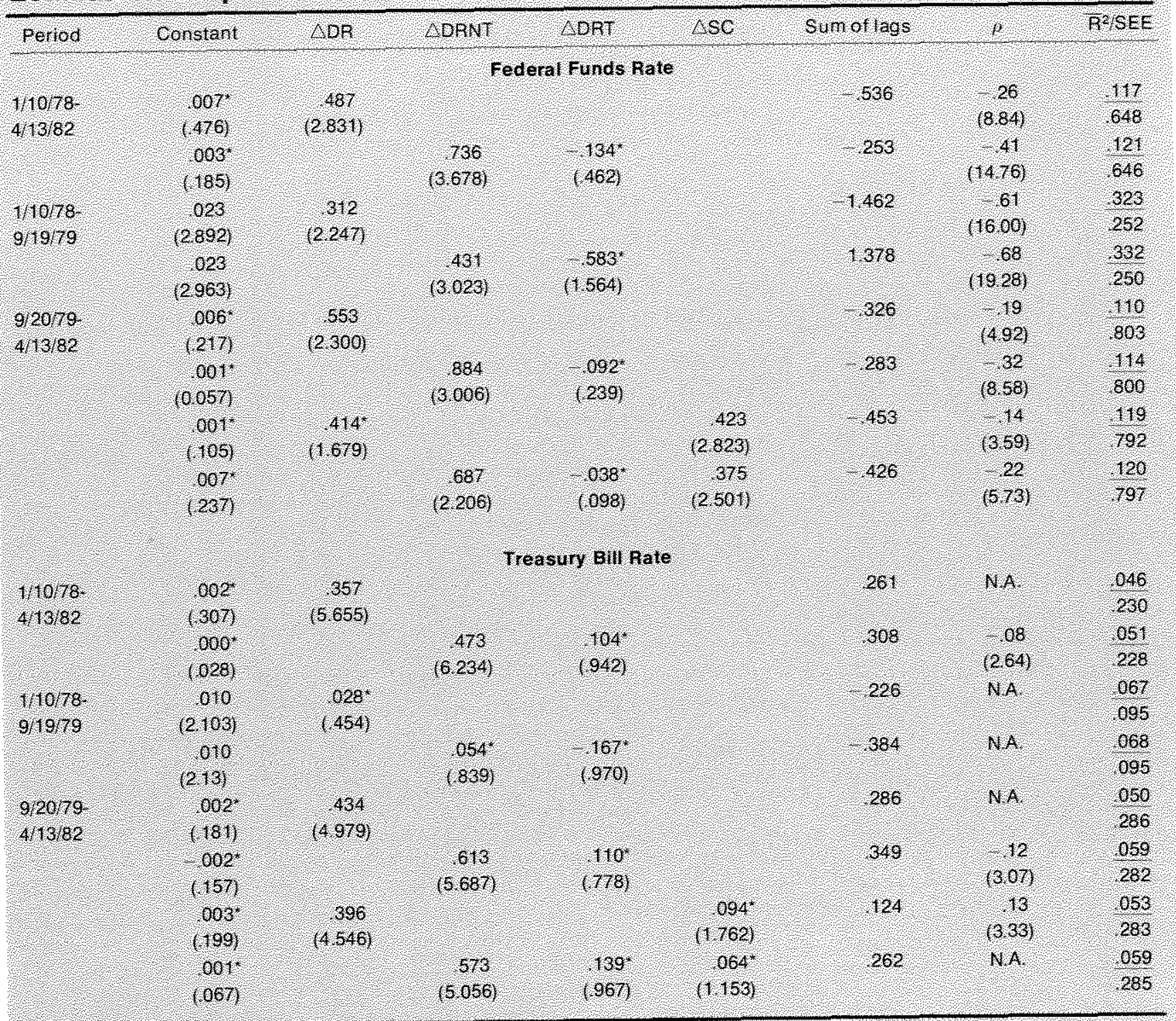

The absolute watle of the hralos are h porentheses below each coefficient

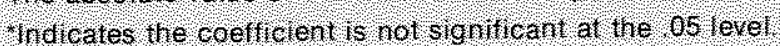

N.A halcates the equation was estinated with ordmary least squares.

ing period. Hence, discount rate changes may not have been anticipated as well during this period, resulting in a more significant announcement effect on the demand side.

Furthermore, the absolute value of discount rate changes were larger in the latter period. The nine discount rate changes in the early period averaged 50 basis points, while each of the 11 changes in the latterperiod were 100 basis points in absolute value. Thus, one could argue that only larger discount rate changes have a significant effect on market interest rates.

To further investigate the relationship between discount rate changes and market interest rates, the equations were re-estimated using both $\triangle D R N T$ and $\triangle D R T$, which reflect nontechnical and technical 


\section{Reasons for Changes in the Discount Rate}

\begin{tabular}{|c|c|c|}
\hline Date. & Change & Beason \\
\hline May 11, 1978 & $6 / 2107 \%$ & Action taken to bring discount rate n closer alignment with short-tem interest rates. \\
\hline $141 y 31978$ & $7107 \%$ & Essentally the same as above \\
\hline August 21,1978 & $71 / 67 \% \%$ & Action taken in view of recent disordery conditions in toreign exchange markets, as \\
\hline September 22,1978 & $73 / 08 \%$ & 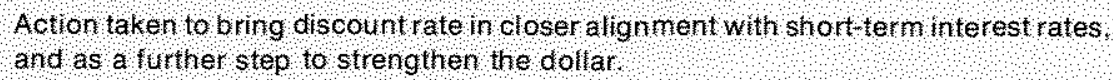 \\
\hline $0010 b e 16,1978$ & $8108 \% 2 \%$ & 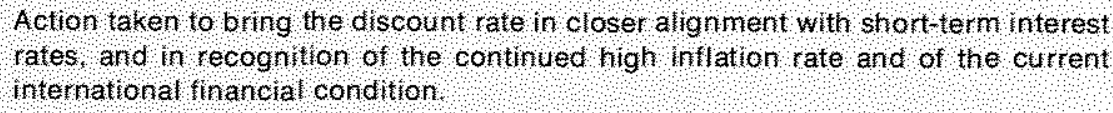 \\
\hline Novenber 1,1978 & $81 / 1091 / 2 \%$ & $\begin{array}{l}\text { Action takento strengthen the dollarand to counter continuing domestio nitlationary } \\
\text { pressures }\end{array}$ \\
\hline July 20,1979 & $9 / 21010 \%$ & $\begin{array}{l}\text { Action taken in view of the recent rop id expansion of the monetary aggregates, to: } \\
\text { strengthen the dollat on toregn exchange narkets and to bring the discount rate } \\
\text { into alignnent with short term interest rates. }\end{array}$ \\
\hline August 17,1979 & $101010 \% \%$ & $\begin{array}{l}\text { Action taken in view of the continuing strong itfationary forces and the relatively } \\
\text { rapid expansion ho the monetany aggregates }\end{array}$ \\
\hline September 19, 1979 & $101401 \%$ & 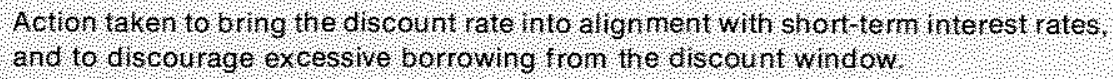 \\
\hline Octobser 9,1979 & $110 \%$ & $\begin{array}{l}\text { Action laken lo orrig discount rate nio closel algnnent with storterm rates, } \\
\text { and to discourage excessive borrowng. }\end{array}$ \\
\hline Fobruar, 15,1980 & $12,013 \%$ & 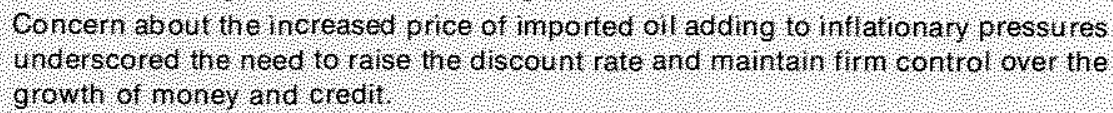 \\
\hline Nay 30,1980 & $13,1012 \%$ & 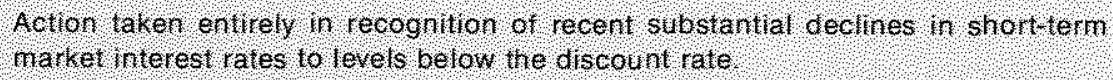 \\
\hline une 13,1980 & $121011 \%$ & Essentialy the same as above. \\
\hline JuY 28,1980 & $111010 \%$ & Essentially the same as above \\
\hline September 26,1980 & $101011 \%$ & 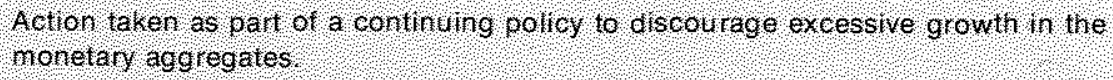 \\
\hline Novenber 7,1980 & $11012 \%$ & 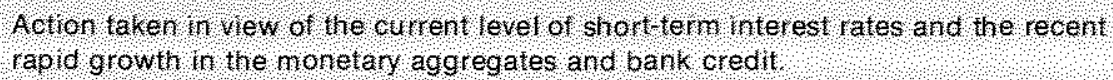 \\
\hline Decenber 5,1980 & $121013 \%$ & 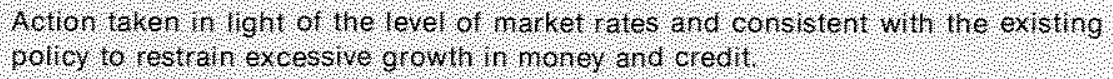 \\
\hline May 5,198 & $131014 \%$ & 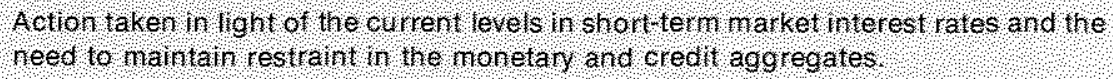 \\
\hline Novembe 2,198 & $44,013 \%$ & 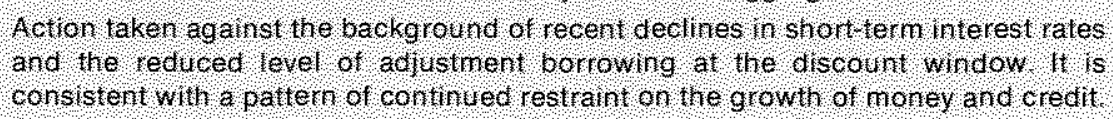 \\
\hline December 4,1981 & $13012 \%$ & 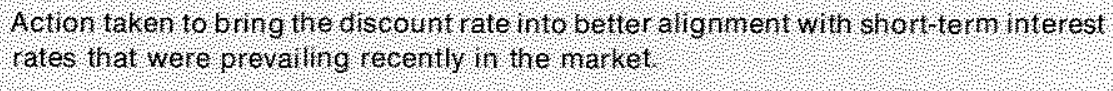 \\
\hline
\end{tabular}

Source federal fesene Bulteths released the nonth of of ore month after he amounced change in he discount rate

changes in the discount rate, respectively. Discount rate changes that are made purely for technical reasons might have less of an impact on market rates in that either (1) the Federal Reserve offsets their effect on the supply of credit through open market operations because they were not intended as a change in policy, or (2) the announcement effect was weaker because market participants do not view such changes as indications of a change in Federal
Reserve policy. ${ }^{27}$ If either of these is true, the coefficient on $\triangle D R N T$ will be larger than the coefficient on $\triangle D R$, and the coefficient in $\triangle D R T$ will not be statistically significant. Table 1 shows that these

27 nnder LRA a change in the riscount rate pudaces a much smalles change in aggregate borrowing than wader contemporaneons reserve accouting. Thus, the leve of open market pperations reguired to of set the effect of this change on money is much smaller. 
results were obtained in every instance. Thus, it appears that only discount rate changes that are made for nontechnical reasons have a significant impact on market interest rates. The coefficient on $\triangle D R N T$ in the Treasury bill rate equation, however, was not significant during the early period. Discount nate changes appear to have had no impact on the 3-month Treasury bill rate under interest rate targeting, regardless of the reason for the change. ${ }^{28}$

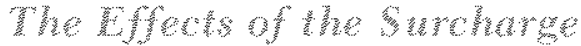

The effects of the discount rate surcharge on market interest rates during the NBR targeting period are mixed. When the discount rate surcharge variable is added to the federal funds rate equation, the coefficients on the discount rate variables become smaller. Futhermore, the coefficients on the surcharge variables are statistically significant. These results indicate a significant positive surcharge effect on the federal funds rate. In addition, they indicate that the estimates of the discount rate effect alone are unduly large when the surcharge variable is ignored. This is likely because of the interaction of discount rate and surcharge effects. ${ }^{29}$

When the surcharge variable is included in the Treasury bill rate equation, the coefficients on the discount rate variables are essentially unaffected. The coefficients on the $\triangle S C$ variable are insignificant and small. Thus, it appears that the surcharge has no appreciable impact on the Treasury bill rate.

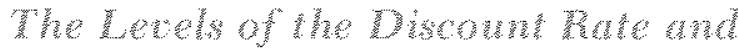

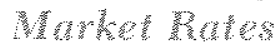

The fact that discount rate changes have a significant immediate effect on market interest rates does not mean that there is a significant relationship between the level of the discount rates and the level of market rates. One would anticipate that any effect of a discount rate change on maket interest rates

\footnotetext{
28The results presented in this section appear to be robust. They are essentially unchanged if the equation is estimated in level form, although the $\mathrm{R}^{2} \mathrm{~s}$ are much larger. Also, essentially the same results are obtamed by a statistical comparison of the oneday percentage changes in the market rates on the day the discount rate change becane effective with the $10-$ any and 20 -day grow th rates prior to the discomt rate change.

291t is important to include the surcharge variable in the lattes period beare some of the changes in the discount rate and the surcharge overlap. The overlapping dates are: November 17 , 1980, December 5,1980 , and May 5, 1981. Failute to inclede the surcharge could result in a spurious estimate of the discount rate effect.
}

would be reflected in market rates rather quickly, so that movement in these rates between discount rate changes would be dominated by other factors. ${ }^{30}$ This is bome out in a casual observation of the relationship between the discount rate and market rates over this period as shown in chart 1 .

It is clear from this chart that market interest rates varied from levels substantially above the discount rate to levels substantially below it over this period. This merely reflects the previously noted fact that there is no level of market interest rates that necessarily corresponds to a given level of the discount rate.

Furthermore, there were at least three occasions when discount rate changes were closely followed by movements in the 3 -month Treasury bill rate in the opposite direction (June 13, 1980, December 5, 1980, and May 5, 1981). In the last instance, the federal funds rate and the Treasury bill rates moved in opposite directions. The federal funds rate rose from early May to mid-July 1981, then declined. In contrast, the bill rate fell from early May to early July, then rose until late August. Thus, it is difficult to find any consistent longer-term relationship between the level of the discount rate and the level of market interest mates.

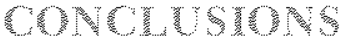

Market interest rates are influenced by numerous factors that affect the supply of and demand for credit. One of these factors is the discount rate. The impact of the discount rate on market rates varies with the Federal Reserve's operating procedures. If the Federal Reserve is controlling interest rates, the monetary base or total reserves, changes in the discount rate have no effect on interest rates independent of the general tenor of monetary policy; the Federal Reserve simply would offset the effect of discount rate changes through open market operam tions. If the Federal Reserve is targeting on nonborrowed reserves, changes in the discount rate are more likely to have an impact on market rates, espe. cially under lagged reserve accounting.

\footnotetext{
30 in an effort to uncover a possible lagged response of the federal funds rate to discount rate changes, equation 4 was estimated with a 20 -day distributed lat of the $\triangle D R$ variable. None of the lagged variables, however, was signiffunt except for the seventh day. It is interesting to note that, sinee most of the discount rate changes becane effective on a Monday, the seventh raly lag wond be Wedresday, the close of the "reserve week." This result, however, is perhaps too tentative to assign any significance to it.
} 


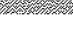

Selected Interest Rates

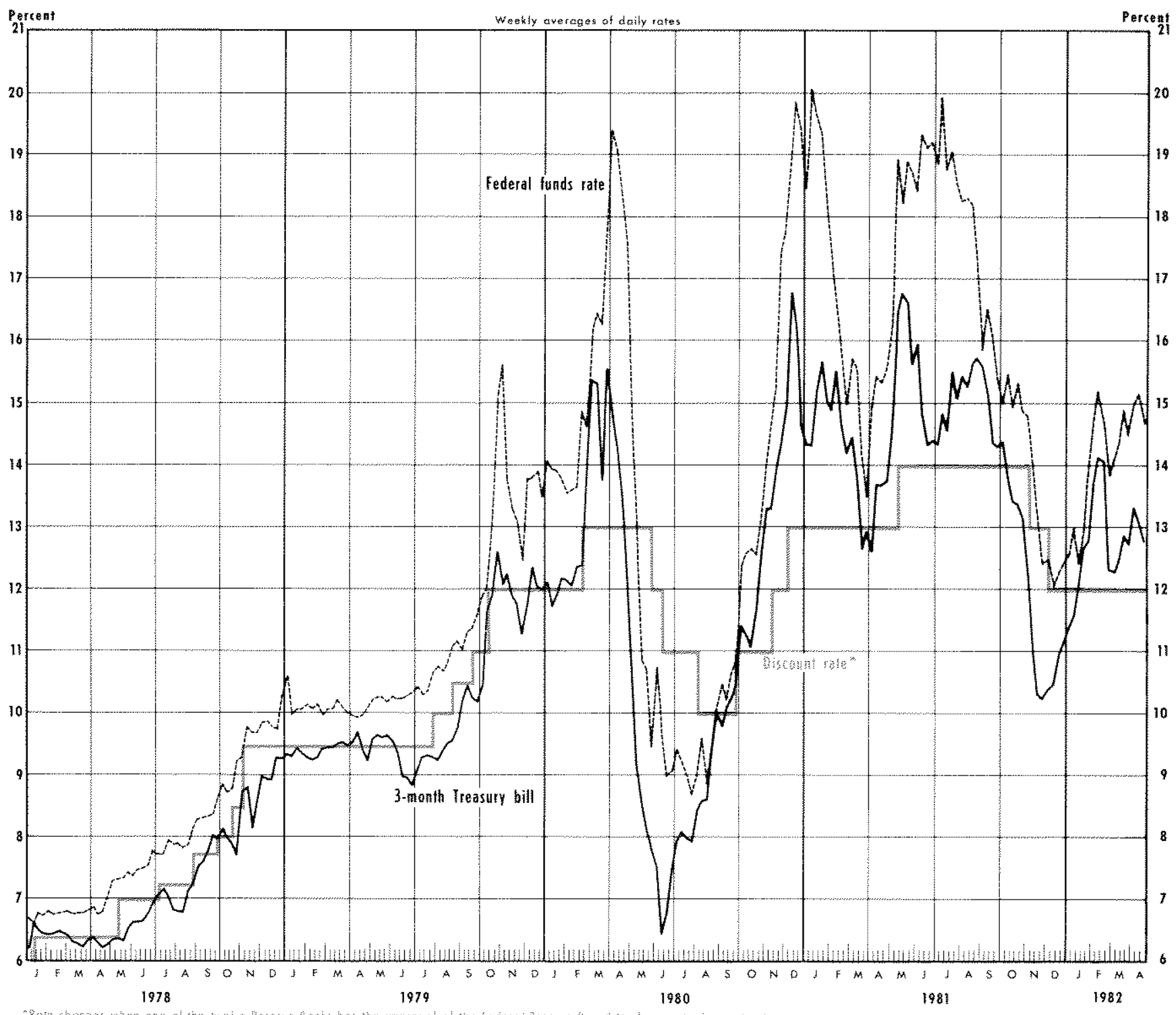

Data indicate that changes in the discount rate have produced a significant, albeit varied, immediate impact on both the federal funds rate and the 3-month Treasury bill rate since January 1978 . The effect of a discount rate change on the federal funds rate was significant for periods of both tederal funds rate targeting and nonborrowed reserve targeting. Discount rate changes significantly affected the Treastry bill rate, however, only in the period of nonborrowed reserve targeting. Furthermore, changes in the discount rate that were made for purely technical reasons had no effect on either market interest rate, while changes in the Federal
Reserve's surcharge on large, frequent borrowers during the nonborrowed reserve targeting period had a significant effect only on the federal funds rate.

There is virtually no evidence, however, that discount rate changes have had a significant, independent effect on market rates in the longer run. Therefore, while changes in the discount rate do produce changes in market interest rates in the short run, they do not appear to be the most significant factor affecting the level of market interest rates in the longer run. 